Basal DA complex:

0 or 1 activator

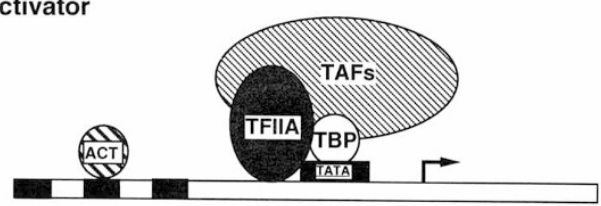

Complex stability

Synergistic DA complex:

multiple activators

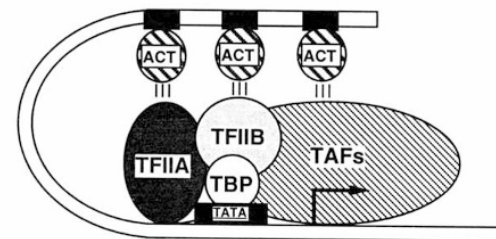

FIG. 4 A general model for gene activation and synergy. Both acidic and non-acidic activators stimulate DA complex formation by interacting with multiple members of the complex. This productive interaction is signalled by a TAF-dependent conformational change leading to an extended DA footprint and recruitment of TFIIB. A single molecule of activator is unable to promote either efficient DA complex formation or recruitment of TFIIB owing to the negative action of TAFs.

activation occurring at a step subsequent to TFIIB recruitment ${ }^{20}$. In contrast, our study suggests that multiple activators, either ZEBRA or GAL4-VP16, assemble the DA complex and subsequently recruit TFIIB in a synergistic fashion. It is plausible that the conditions used in the previous study caused DA binding in the absence of activator, inadvertently bypassing the recruitment we routinely observe. Moreover, the binding of TFIIB only to multiple-site templates in our study may reflect a more stable, and hence probably more functionally relevant, interaction with $\mathrm{DA}$ because the $\mathrm{Mg}$-agarose gel is more stringent. This idea would not contradict Choy and Green ${ }^{20}$, who found that the TFIIB bound to a single-site template generated an inactive complex. Consistent with this idea, TFIIB failed to enhance DA recruitment on a template bearing only one site.

Our DNA binding experiments are largely supported by earlier kinetic data on ZEBRA and GAL4 action using transcription and open complex assays ${ }^{1,5,21}$. Furthermore, our results are in broad agreement with in vivo studies showing that TFIID binding is rate limiting and that an activator affects the kinetics of this process ${ }^{22.23}$. We suggest that the effects observed here, superimposed upon the cooperative binding of activators and the general factors to chromatin ${ }^{24,25}$, could explain the large synergistic transcriptional responses observed in vivo.

Received 10 May; accepted 7 August 1995

1. Chi, T. \& Carey, M. Molec. cell. Biol. 13, 7045-7055 (1993).

2. Gerster, T., Balmaceda, C. G. \& Roeder, R. G. EMBO J. 9, 1635-1643 (1990).

3. Schaffner, G., Schirm, S., Muller-Baden, B., Weber, F. \& Schaffner, W. J. molec. Biol. 201, 81-90 (1988)

4. Miller G. J infect Dis. 161, 833-844 (1990).

5. Lieberman, P. M. \& Berk, A. J. Genes Dev. 8, 995-1006 (1994).

6. Hori, R. \& Carey, M. Curr. Opin. Genet. Dev. 4, 236-244 (1994)

7. Miller, G. et al. J. Virol. 67, 7472-7481 (1993).

8. Carey, M., Lin, Y. S., Green, M. R. \& Ptashne, M. Nature 345, 361-364 (1990)

9. Carey, M. et al. J. Virol. 66, 4803-4813 (1992).

10. Van Dyke, M. W. \& Sawadogo, M. Molec. cell Biol. 10, 3415-3420 (1990)

11. Horikoshi, M., Hai, T., Lin, Y. S. Green, M. R. \& Roeder, R. G. Cell 54, 1033-1042 (1988).

12. Horikoshi, M., Carey, M. F., Kakidani, H. \& Roeder, R. G. Cell 54, 665-669 (1988).

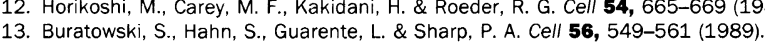

13. Buratowski, S., Hahn, S., Guarente, L. \& Sharp, P. A. Cell

15. Lieberman, P. M. \& Berk, A. J. Genes Dev. 5, 2441-2454 (1991).

16. Goodrich, J. A., Hoey, T., Thut, C. J., Admon, A. \& Tjian, R. Cell 75, 519-530 (1993)

17. Lin, Y. S. \& Green, M. R. Cell 64, 971-981 (1991)

18. Tjian, R. \& Maniatis, T. Cell 77, 5-8 (1994)

19. Meisterernst, M., Roy, A. L., Lieu, H. M. \& Roeder, R. G. Cell 66, 981-993 (1991).

20. Choy, B. \& Green, M. R. Nature 366, 531-536 (1993).

20. Choy, B. \& Green, M. R. Nature 366, 531-536 (1993).

22. Klein, C. \& Struhl, K. Science 266, 280-282 (1994).

23. Colgan, J. \& Manley, J. L. Genes Dev. 6, 304-315 (1992)

24. Adams, C. C. \& Workman, J. L. Molec. cell. Biol. 15, 1405-1421 (1995)

25. Taylor, I. C., Workman, J. L., Schuetz, T. J. \& Kingston, R. E. Genes Dev. 5, 1285-1298 (1991).

26. Zhou, Q., Lieberman, P. M., Boyer, T. G. \& Berk, A. J. Genes Dev. 6, 1964-1974 (1992).
27. Ozer, J. et al. Genes Dev. 8, 2324-2335 (1994).

28. Ha, L. Lane W. S. \& Reinberg. D. Nature 352, 689-695 (1991)

29. Ha, l. et al. Genes Dev. 7, 1021-1032 (1993).

ACKNOWLEDGEMENTS. T.C. and P.L. contributed equally to this work. We thank A. Berk, S. Smale, M. Ptashne, M. Green, K. Struhl, B. Kingston and members of the Carey lab for helpfu discussions. This work was supported by a grant from the American Cancer Society to M.C.

CORRECTIONS

\section{An efficient prebiotic synthesis of cytosine and uracil}

\author{
Michael P. Robertson \& Stanley L. Miller \\ Nature 375, $772-774$ (1995)
}

IN this report on the prebiotic synthesis of cytosine from cyanoacetaldehyde and urea, related work that should have been cited was omitted. The prebiotic synthesis of cytosine from $1 \mathrm{M}$ cyanoacetylene and $1 \mathrm{M}$ urea in $4.8 \%$ yield was reported earlier by J. P. Ferris, R. A. Sanchez and L. E. Orgel (J. molec. Biol. 33, 693-704; 1968). Replacing cyanoacetylene by its hydrolysis product cyanoacetaldehyde gives essentially the same yield, suggesting that the cyanoacetylene reaction may have gone through cyanoacetaldehyde. The concentrated urea solution $(20 \mathrm{M})$ postulated in a drying-lagoon model of prebiotic synthesis results in yields of cytosine as high as 53\%.

\section{Short alanine-based peptides may form $3_{10}$-helices and not $a$-helices in aqueous solution}

\author{
Siobhan M. Milick, Gary V. Martinez, \\ Wayne R. Fiori, A. Paul Todd \\ \& Glenn L. Millhauser
}

Nature 359, 653-655 (1992)

THE originally reported ESR spectrum for the $3 \mathrm{~K}-(4,8)$ peptide exhibited artificially sharp features due to the presence of a monoradical contaminant. The peptide has since been repurified and the proper spectrum reported ${ }^{1}$. Linewidth measurements indicate that the biradical interaction between the spin labels is weaker in the repurified $3 \mathrm{~K}-(4,8)$ peptide than in the $3 \mathrm{~K}-(4,7)$, which continues to support the original observation that $d(4,7)<d(4,8)$. Thus, the conclusion of the original paper-that the $3 \mathrm{~K}$ peptide contains a significant proportion of $3_{10}$-helixremains intact. We are indebted to $M$. D. Rabenstein and Y. K. Shin for bringing this matter to our attention and for suggesting improved methods of peptide purification.

1. Millhauser, G. L. Biochemistry 34, 3873-3877 (1995).

\section{ERRATUM}

\section{Peripheral deletion of antigen-reactive $\mathbf{T}$ cells in oral tolerance}

\section{Youhai Chen, Jun-ichi Inobe, Reinhard Marks, Patricia Gonnella, Vijay K. Kuchroo \& Howard L. Weiner}

Nature 376, 177-180 (1995)

PANELS $a-c$ of Figs 2 and 3 of this Letter were accidentally transposed during the production process. 